\title{
Mapping Forest Cover Changes using Sentinel-2A Imagery in the Municipality of Zubin Potok, Republic of Kosovo
}

\author{
Ferat KRASNIQI ${ }^{\mathrm{a} *}$ - Géza KIRÁLY ${ }^{\mathrm{b}}$ \\ ${ }^{a}$ Department of Geography, Faculty of Mathematics and Natural Sciences, University of Prishtina "Hasan \\ Prishtina", Prishtina, Kosovo \\ ${ }^{\mathrm{b}}$ Institute of Geomatics and Civil Engineering, Faculty of Forestry, University of Sopron, Sopron, Hungary
}

\begin{abstract}
This research aimed to investigate the changes in forest cover, utilizing Sentinel-2A imagery data. Annual results of deforestation, non-forest, and forest area in the Municipality of Zubin Potok (Kosovo) between 2016 and 2017 were presented and analyzed by applying the image difference change detection method on a Normalized Difference Vegetation Index (NDVI) product derived for both years. The study reveals that forest coverage in this municipality has changed due to human activity (harvested and burnt forests). The footprint of changes was evidenced by using Sentinel 2A band combinations and very high resolution (VHR) images available in Google Earth (GE). From the overall forest-covered area of 24,873.61 hectares, the detected changes during the annual period are as follows: $24,423.57$ ha or $98.19 \%$ is mapped as forest, 113.75 hectares or $0.46 \%$ as non-forest, and 336.77 or $1.35 \%$ of the area forest is mapped as deforestation. These results can be used to identify human-made deforestation and to develop monitoring forest plans for the coming years.
\end{abstract}

deforestation / reforestation / vegetation indexes / change detection / sample design / accuracy assessment

Kivonat - Az erdőterület-változása Sentinel-2A ürfelvételek alapján Zubin Potok község határában, Koszovóban. A tanulmány Sentinel-2A müholdfelvételek alapján egy erdősült terület változását vizsgálja. Az erdőterület éves változását 2016 és 2017 között Zubin Potok (Koszovó) községhatárában mutatja be és elemzi a felvételek vegetációs index (NDVI) alapú változása alapján. A tanulmány megállapítja az emberi tevékenység (fakivágás) és az erdőtűz okozta területváltozásokat a községhatárban. A változásokat a Sentinel-2A ürfelvétel és a Google Earth (GE) felvételek egyértelmüvé teszik. A teljes 24 873,61 hektáros erdőterületből az éves időszakban észlelt változások a következők: 24 423,57 ha vagy 98,19 \% erdőként, 113,75 hektár vagy $0,46 \%$ nem erdőként és 336,77 vagy 1,35 \% -a az erdőt erdőirtásként ábrázolják. Ezek az eredmények felhasználhatók az ember által okozott erdőirtások azonosítására és a következő évekre vonatkozó erdőterv kidolgozására.

erdőirtás / erdőfelújítás / vegetációs indexek / változás vizsgálata / mintavétel kialakítása / pontosság-vizsgálat

"Corresponding author: ferat.krasniqi@uni-pr.edu; XKX-10000 PRISHTINA, Mother Theresa-Street, N.N, Republic of Kosovo. 


\section{INTRODUCTION}

Recently, the increased amount of imagery data coming from remote sensing technology empowered the science community and beyond to study and research important aspects of land cover and use changes on the living environment. Information on land cover and land use change inventory are essential data for different environmental issue implementations such as; deforestation, estimated devastations, disaster observations, urban growth, land management, and land planning (Hussain et al. 2013). According to Achard et al. 2009, INPE 2014, FAO, JRC, SDSU, and UCL 2009 as cited in (Hojas-Gascón et al. 2015) "for more than a decade the monitoring of deforestation has successfully been carried out at regional levels using medium-spatial resolution satellite data, predominantly from the Landsat sensor, which has 30 m spatial resolution and a revisit frequency of 16 days". In 1997, the World Resources Institute (WRI) founded the Global Forest Watch (GFW) as an initiative for forest frontiers, reporting only on a few pilot countries at the beginning until growing as an online global platform that provides data and tools for anyone to enter and obtain information on how and where forest cover is changing (WRI 2019).

Another valuable online inventory of the land cover product is Copernicus - the European Union's Earth Observation Programme, served by imagery data from the Sentinel satellite family. The Copernicus Land Monitoring Service (CLMS) delivers spatial information on land cover use and its changes, vegetation, and other products in the field of environmental land applications to a wide array of clients in Europe and across the world (EEA 2018).

Various image transformation indexes among spectral bands of various satellite sensors have been created for monitoring vegetation status on a continental and global scale including the most broadly applied Normalized Difference Vegetation Index (NDVI) using the Advanced Very High Resolution Radiometer (AVHRR) sensor on board the NOAA series of satellites (CCRS 2019) and Moderate Resolution Imagine Spectroradimeter (MODIS) sensors on the Terra and Aqua satellites. These both have high temporal resolution (one day revisit time) and their reflectance data are convenient for time series vegetation dynamic analysis at regional and global scales. However, due to their very coarse spatial resolution of $1 \mathrm{~km}$ (AVHRR) and $250 \mathrm{~m}$ (MODIS), the investigation of phenological dynamics is problematic for finer or local scale vegetation status monitoring (Walker et al. 2012).

Furthermore, Landsat series of satellites provides the longest and richest archive (over 40 years) of systematically collected remotely sensed data (Goward et al. 2006) with valuable information and possibilities for enhanced knowledge of methods and extents of past forest changes and recovery (Banskota et al. 2014). In addition, a $30 \mathrm{~m}$ spatial resolution and 16-day repetitive temporal resolution makes Landsat data well suited for land cover monitoring of the Earth's surface (Gillanders et al. 2008). Concerning the diverse possibility of remotely sensed data from both optical and radar sensors, monitoring an environmental phenomenon employing temporal and spatial resolutions of the data is reduced to five days and higher spatial resolution to $10 \mathrm{~m}$ with the launch of the Sentinel-2 mission by ESA in June 2015. In remote sensing (RS) technology, the common intention of the change detection approach is to point out the geographic position of land cover changes, change calculation, and map result validation (Coppin et al. 2004, Im - Jensen 2005, Macleod - Congalton 1998).

The Normalized Difference Vegetation Index (NDVI) is a widely used vegetation index because it is useful in remotely sensed data calculation (Huete - Liu 1994) and strongly revealed global vegetation cover monitoring in the past two decades (Leprieur et al. 2000). According to Singh (1989), change detection is "the process of identifying differences in the state of an object or phenomenon by observing it at different times". Brothers and Fish as well as Malila and Singh, as cited (Macleod - Congalton 1998), reported: "four aspects of change 
detection are important when monitoring natural resources: (1) detecting that changes have occurred, (2) identifying the nature of the change, (3) measuring the areal extent of the change, and (4) assessing the spatial pattern of the change". For improved understanding, the change detection method types are grouped into seven categories: 1. algebra, 2. transformation, 3. classification, 4. advanced models, 5. Geographical Information System GIS approaches 6. visual analysis, and 7. other approaches (Lu et al. 2004b). The change detection technique is one of the key implementations in remote sensing (RS), moreover using bi-temporal or multi-temporal data imagery (Campbell - Wynne 2011). According to Singh (1989, p. 990), "there are two basic approaches for change detection; (1) comparative analysis of independently produced classification for different dates and (2) simultaneous analysis of multi-temporal data". The image difference technique requires two accurately co-registered image data sets in order to generate a new subtracted image, the values of which indicate the changes (Hussain et al. 2013). Although different change detection techniques are currently available, they are difficult and require choosing an appropriate algorithm to achieve change detection results practically (Lu et al. 2004). Therefore, defining an appropriate threshold for mapping class change category is one of the most critical steps (Lu et al. 2005). The application of image thresholding in computer vision is to segment the objects based on the image pixel intensities by using a grayscale image as input and threshold, and the result is a binary image.

Checking accuracy assessment is an essential part of any project that deals with remotely sensed data. Many reasons that emphasize the significance of the accuracy assessment exist: "1) the need to know how well you are doing and to learn from your mistakes; 2) the ability to quantitatively compare methods; and 3) the ability to use the information resulting from your spatial data analysis in some decision-making process" (Congalton 2001, p. 321).

An error matrix table successfully describes a precise classification map by containing commission and omission mistakes. A commission error indicates the pixels or areas are wrongly assigned to that map category, while an omission error represents the pixels or areas correctly assigned to that map category (Congalton - Green 2009). Use of the error matrix table is also possible to calculate other measures of classification change validation such as overall accuracy as well as produce and user accuracy (Story - Congalton 1986).

The existing literature on the status of forest monitoring using remotely sensed data is quite applicable. Deforestation and reforestation are common environmental topics across the world. The direct human cause of forest land transformation to a non-forested land was defined as deforestation and the transformation of non-forest land (which was previously covered under forests) into the human-induced forest through the planting of seedlings, or the planting of natural seeds is defined as reforestation (UNFCCC 2002).

Based on the National Forest Inventory Kosovo 2012 Report (Tomter et al. 2013), forests cover an area of 481,000 hectares or $44.7 \%$ of the total country land area, which is dominated by deciduous forest $(93 \%)$, coniferous forest (5\%), and mixed forest $(2 \%)$. Concerning the status of Kosovo loggings, according to this report, the annual permitted logging level allowed is about 1.4 million $\mathrm{m}^{3}$. This level was exceeded by an estimated 1.6 million $\mathrm{m}^{3}$ of annual loggings. In addition, 7\% of loggings were conducted according to forest legislation and around 12,200 hectares, or $2.5 \%$ of the total forest areas, were severely burned. The data analyzed from this report constitute the reason for increased study of the state of forests in Kosovo. Therefore, we have decided to investigate the forest changes in a one-year difference (2017-2016) in this study area and address the following research objectives: How can deforestation be detected and mapped? How can non-forested areas that have been previously deforested be detected and mapped? Is there any human intervention involved in the reforestation? 


\section{MATERIALS AND METHODS}

\subsection{Study area}

Defining the study area was one of the research challenges. The forest area examined for this study is located in the municipality of Zubin Potok in the northern part of the Republic of Kosovo, located between the latitudes $42^{\circ} 48.507 \mathrm{~N}$ and $43^{\circ} 2.120^{\prime} \mathrm{N}$ and longitudes $20^{\circ}$ $29.076^{\prime} \mathrm{E}$ and $20^{\circ} 47.839^{\prime} \mathrm{E}$. The area extends over $333 \mathrm{~km}^{2}$ and has a population of 6,616 (KSA 2013). In its southern part, this municipality borders Istog and Skënderaj, while in its eastern part it borders Zveçan. Its entire western part borders Serbia (Figure 1). The area is characterized by mainly mountainous relief and scattered settlements. Its main economic branch is agriculture. The area is also home to an artificial accumulation of the lake of Ujman (Gazivoda). In addition to being of great importance for the municipality and the country, the lake is one of the largest artificial lakes in Kosovo with an extended surface of $9 \mathrm{~km}^{2}$.

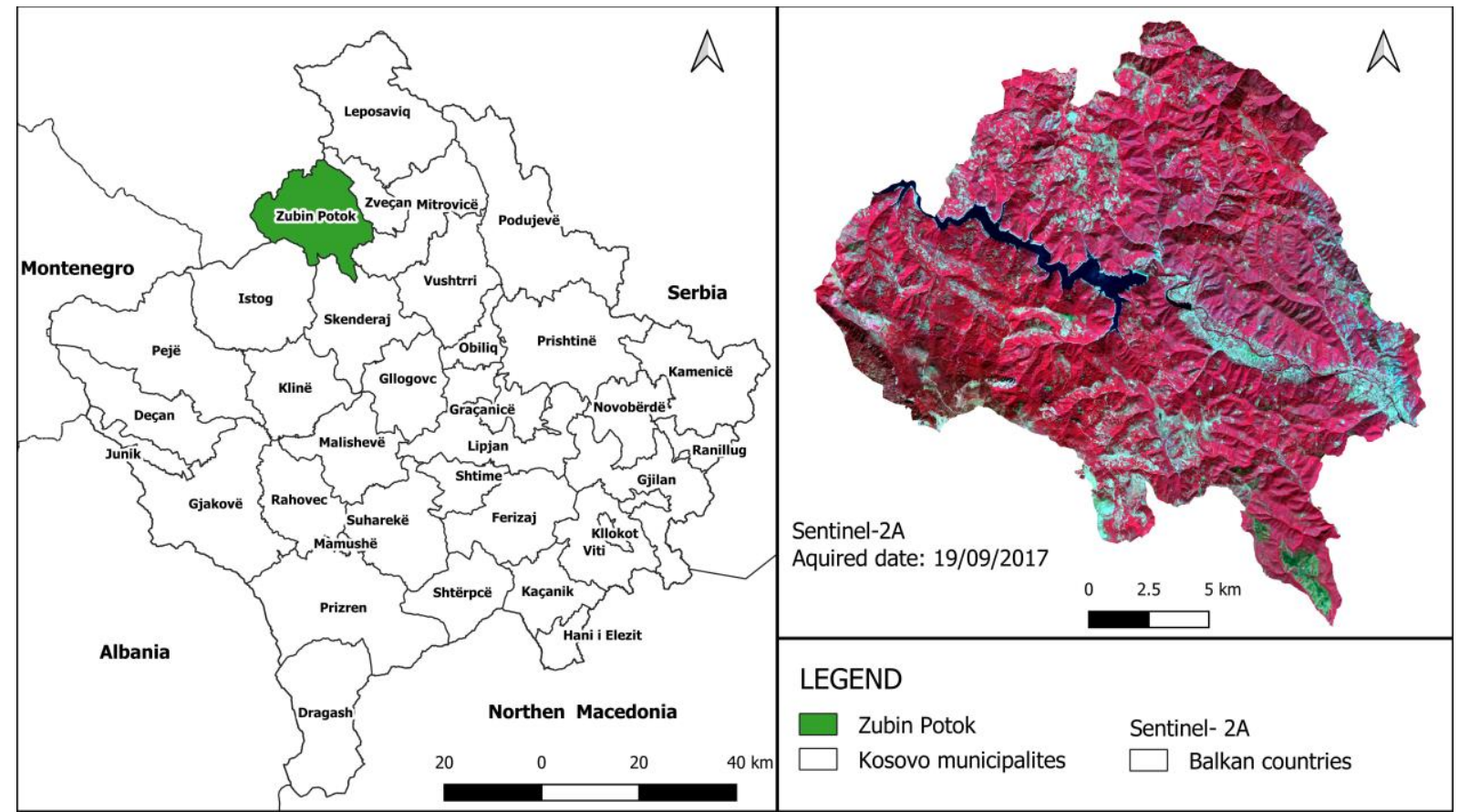

Figure 1. The geographical location of the study area in Kosovo (left), and Sentinel $2 A$ color composite map (right). The map to the right of Figure 1 used in this study is a color composite image of these bands combination: NIR, RED, and GREEN. The red color on the map indicates forest vegetation; the green color represents deforestation, the blue color represents the water surface, the cyan, and other colors represent the surfaces not covered with forests (settlements, roads, bare land, agricultural areas, etc.).

According to CLC (CORINE Land Cover), 2018 inventory (EEA, 2018), 24,850.32 hectares $(77.43 \%)$ of the total area of the municipality - 33,385.6 ha $(100 \%)$ - is forest covered (deciduous, coniferous, and mixed), 3,207.28 ha $(9.61 \%)$ is semi-forested (meadows and shrubs), 4,133.42 hectares (12.38\%) are agricultural, 774.21 ha (2.32 \%) waters (lakes and rivers), and 129.32 ha $(0.39 \%)$ of the surface is a built-up area.

\subsection{Imagery Data and their Processing}

The multi-spectral imagery data set of Sentinel satellite platforms $2 \mathrm{~A}$ has been used as a primary source. Two cloud-free images were selected from 15/08/2016 and 19/09/2017 and 
downloaded from the Copernicus Data and Information Access Services (DIAS) via the Mundi web services platform (https://mundiwebservices.com/). Sentinel-2A satellite has 13 spectral bands from visible through near-infrared to shortwave infrared: four image bands at $10 \mathrm{~m}$, six bands at $20 \mathrm{~m}$, and three other bands at $60 \mathrm{~m}$ spatial resolution (ESA 2015).

Table 1. The spatial and spectral resolution of Sentinel 2-A bands

\begin{tabular}{clccc}
\hline $\begin{array}{c}\text { Band } \\
\text { number }\end{array}$ & Band name & $\begin{array}{c}\text { Spatial resolution } \\
(\mathrm{m})\end{array}$ & $\begin{array}{c}\text { Central } \\
\text { wavelength } \\
(\mathrm{nm})\end{array}$ & $\begin{array}{c}\text { Bandwidth } \\
(\mathrm{nm})\end{array}$ \\
\hline 2 & Blue & 10 & 492.4 & 98 \\
3 & Green & & 559.8 & 45 \\
4 & Red & & 664.6 & 38 \\
8 & NIR & 20 & 832.8 & 145 \\
5 & Vegetation Red Edge (VRE) & & 704.1 & 19 \\
6 & Vegetation Red Edge (VRE) & & 740.5 & 18 \\
7 & Vegetation Red Edge (VRE) & & 782.8 & 28 \\
$8 \mathrm{a}$ & Vegetation Red Edge (VRE) & & 864.7 & 33 \\
11 & SWIR & & 1613.7 & 143 \\
12 & SWIR & & 2202.4 & 242 \\
1 & SWIR & 60 & 442.7 & 27 \\
9 & SWIR & & 945.1 & 26 \\
10 & SWIR & & 1373.5 & 75 \\
\hline
\end{tabular}

Source: (https://earth.esa.int/web/sentinel/user-guides/sentinel-2-msi/resolutions/radiometric)

The Sentinel-2 mission is a constellation of two satellites (Sentinel-2A and Sentinel-2B) that provide high-resolution optical imagery on global coverage of Earth's land surface. Every ten days it revisits every single satellite and every five days with the combined constellation of the second satellite, making the data of great use for land monitoring studies (Addabbo et al. 2016).

Processing Level-1C and Level-2A of MSI Sentinel 2A products are freely available to users. The Level-2A processing of MSI Sentinel-2A data contains a Scene Classification and an Atmospheric Correction applied to Top-Of-Atmosphere (TOA) Level 1C orthoimage products (ESA 2015). The main output is an orthoimage Bottom-of-Atmosphere (BOA) corrected reflectance product, resampled and generated with an equal spatial resolution for all bands, and it can be used at the request of users in three levels of spatial resolution: $10 \mathrm{~m}, 20$ $\mathrm{m}$, and $60 \mathrm{~m}$ (ESA 2015). The metadata of Sentinel-2A, such as a product item, spacecraft name, processing level, product type delivered, and the date of acquired imageries is described in Table 2.

Table 2. Main metadata of the selected Sentinel-2A imageries

\begin{tabular}{cccc}
\hline Product & Spacecraft name & Processing level & Acquisition time \\
\hline S2A_MSIL2A_20160815T09304 & Sentinel - 2A & Level-2A & 2016-08-15 \\
2_S0100_R136_T34TDN_20160 & & & \\
815T093218 & & & \\
S2A_MSIL2A_20170919T09303 & Sentinel-2A & Level-2A & 2017-09-19 \\
1_N0205_R136_T34TDN_20170 & & & \\
919T093732 & & & \\
\hline
\end{tabular}




\subsection{Methodology}

To complete the research objective, the following methodology was applied. A $10 \mathrm{~m}$ spatial resolution of Level-2A of MSI Sentinel-2A spectral bands: 2 (Blue), 3 (Green), 4 (Red), and 8 (NIR) covering the study area downloaded. Spatial and spectral subset and layer stacking of an orthoimage Sentinel-2A corrected reflectance images was realized by the raster tool in QGIS. The Sentinel-2A bands 4 (RED) and band 8 (NIR) that belong to the visible and nearinfrared (VNIR) electromagnetic spectrum were selected for further use. NDVI 2016 and $\mathrm{NDVI}_{2017}$ maps creation is the main step to proceed further with change detection analysis. NDVI is calculated by dividing the surface reflectance difference between near-infrared (NIR; $0.842 \mu \mathrm{m})$, and visible red $(\mathrm{R} ; 0.665 \mu \mathrm{m})$ spectral bands by their sum, given in a value between -1 and 1 (Tucker et al. 1985):

$$
\mathrm{NDVI}=(\mathrm{NIR}-\mathrm{R}) /(\mathrm{NIR}+\mathrm{R})
$$

To conduct change detection analysis in the forest area, the following tasks such as image difference, image threshold, and refinement of the change detection results, were undertaken by using the Image Change Workflow tool in ENVI 5.3 software. The image difference method could be performed directly on a single band image or a single transformation image. The formula to calculate the difference change image is:

$$
\mathrm{dNDVI}_{(2016-2017)}=\mathrm{NDVI}_{2016}-\mathrm{NDVI}_{2017}
$$

An image difference algorithm was applied by subtracting NDVI 2016 from $\mathrm{NDVI}_{2017}$, to create a difference NDVI (dNDVI 2016-2017) map. To detect and map the changes in the forest area, Otsu's threshold algorithm by auto-default settings is applied on the $\mathrm{dNDVI}_{(2016-2017)}$ grayscale image. Otsu (1979) introduced the discriminant criterion $\eta$ as a ratio between-class variance and total variance (total $=$ between-class + within-class variance). He proved that the optimal threshold $\mathrm{k}$ maximizes the ratio $\eta$ or equivalently maximizes the between-class variance. The equation below describes the calculation of the threshold using two options:

Within class variance:

$$
\sigma_{\omega}^{2}(t)=\omega_{0}(t) \sigma_{0}^{2}(t)+\omega_{1}(t) \sigma_{1}^{2}(t)
$$

Where $\omega_{0}$ and $\omega_{1}$ are the probabilities of the two clusters separated by a threshold $(t), \sigma_{0}^{2}$ and $\sigma_{1}^{2}$ are the class variances. From the $L$ bins of the histogram is computed the class probability $\omega_{0,1}(t)$ :

$$
\begin{gathered}
\omega_{0}(t)=\sum_{i=0}^{t-1} p(i) \\
\omega_{1}(t)=\sum_{i=t}^{L-1} p(i)
\end{gathered}
$$

Between class variance:

$$
\sigma_{b}^{2}(t)=\omega_{0}(t) \omega_{1}(t)\left[\mu_{0}(t)-\mu_{1}(t)\right]^{2}
$$

Where, $\omega$ express class probabilities; $\mu$ express class means. The class means $\mu_{0}(t)$, $\mu_{1}(t)$ and $\mu_{T}$ are computed: 


$$
\begin{aligned}
& \mu_{0}(t)=\frac{\sum_{i=1}^{t-1} i p(i)}{\omega_{0}(t)} \\
& \mu_{1}(t)=\frac{\sum_{i=1}^{L-1} i p(i)}{\omega_{1}(t)} \\
& \mu_{T}=\sum_{i=t}^{L-1} i p(i)
\end{aligned}
$$

There is a possibility that all the following relations can be easily verified:

$$
\begin{gathered}
\omega_{0} \mu_{0}+\omega_{1} \mu_{1=} \mu_{T} \\
\omega_{0}+\omega_{1}=1
\end{gathered}
$$

Repetitively the calculation of class means and class probabilities can be done. This brings an effective algorithm:

1. Compute the histogram and intensity level probabilities

2. Initialize $\omega_{1}(0)$ and $\mu_{1}(0)$

3. Iterate through all possible thresholds: $t=1, \ldots$ max. intensity

3.1. Update $\omega_{1}$ and $\mu_{1}$

3.2. Compute $\sigma_{b}^{2}(t)$

4. The max. $\sigma_{b}^{2}(t)$ value is the final threshold.

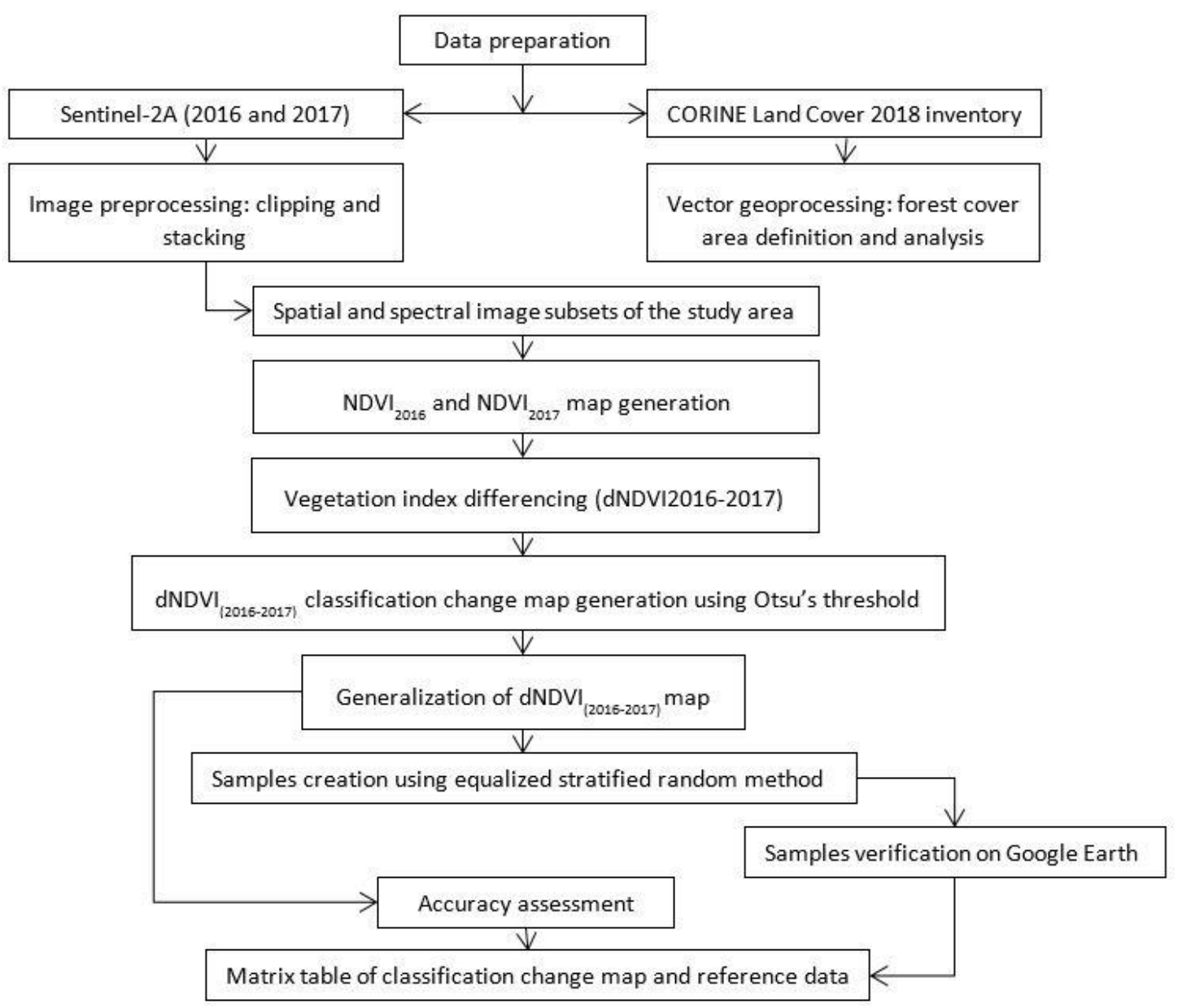

Figure 2. Flowchart depicting the working methodology in this research 


\section{RESULTS AND ANALYSIS}

This paper analyzed forest cover changes in the Municipality of Zubin Potok from 2016 to 2017 by utilizing the vegetation index difference method of change detection algebra technique on the Sentinel-2A imagery data. Result interpretation is described in the following chapters.

\subsection{NDVI maps}

In this study, the RED (4) and NIR (8) bands of the Sentinel- 2A at 10m spatial resolution were used to generate $\mathrm{NDVI}_{2016}$ and $\mathrm{NDVI}_{2017}$ maps using the NDVI equation (1). In practice, water bodies, bare ground, artificial features, and other non-vegetative areas correspond below 0.1 NDVI values; and higher values indicate a higher photosynthetic activity such as shrubs, grasslands, crops, temperate, and tropical forest (Meneses-Tovar 2011/12).

Table 3. Normalized difference vegetation indexes (NDVI 2016 and $\left.N D V I_{2017}\right)$ basic statistics

\begin{tabular}{|c|c|c|}
\hline Statistics & NDVI 2016 & NDVI 2017 \\
\hline Minimum & -0.98 & -0.88 \\
\hline Mean & 0.86 & 0.84 \\
\hline StdDev & 0.08 & 0.11 \\
\hline Maximum & 0.99 & 1.00 \\
\hline
\end{tabular}

Table 3 presents the basic statistics of $\mathrm{NDVI}_{2016}$ and $\mathrm{NDVI}_{2017}$ maps, such as minimum, mean, standard deviation, and maximum.

Figure 3 presents the $\mathrm{NDVI}_{2016}$ and $\mathrm{NDVI}_{2017}$ maps, and their values indicate the spatial distribution differences of forest cover between years. The color ramp from yellowish to reddish of the $\mathrm{NDVI}_{2017}$ map in the southeastern part of the study indicates the area with negative values or no vegetation due to fires or forest cutting by human activity. However, more detailed interpretations of the NDVI maps will be explained by applying the vegetation index difference method.

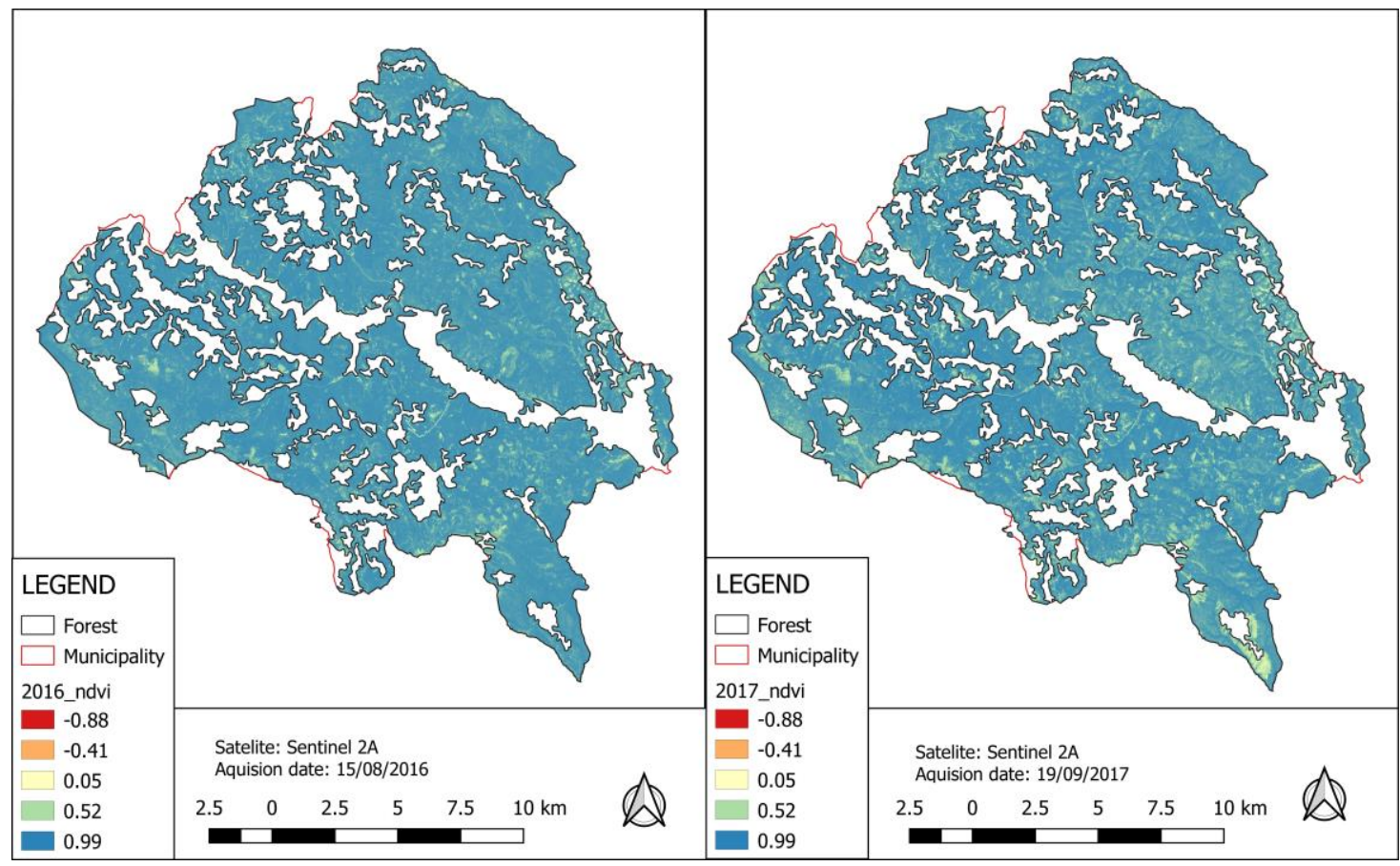

Figure 3. The Normalized difference vegetation indexes - NDVI 2016 (left) and NDVI 2017 maps (right) of the study area 


\subsection{Difference NDVI maps}

By applying the image difference method on NDVI pairs, the result is the image difference NDVI output. The color ramp of the difference image dNDVI $2016-2017$ map presented in Figure 5 reveals the different intensity of pixels which indicate the differences in vegetation condition between annual years, either forest loss or forest growth. The histogram of the newly created difference image has both negative and positive pixel values. Pixels with negative and positive values indicate the changing area by scattering on the edges of the distribution curve (Singh 1989) when pixels with zero or close to zero values indicate unchanged by scattering around the zero (Lu et al. 2005). Figure 4 shows the distribution curve of difference image $\mathrm{dNDVI}_{(2016-2017)}$, while table 4 shows the basic statistics of difference $\mathrm{dNDVI}_{(2016-2017)}$.

Table 4. Difference of $N^{2} \mathrm{II}_{2016}$ and NDVI 2017 basic statistics

\begin{tabular}{cccc}
\hline Minimum & Mean & StdDev & Maximum \\
-0.84 & -0.01 & 0.05 & 1.02 \\
\hline
\end{tabular}

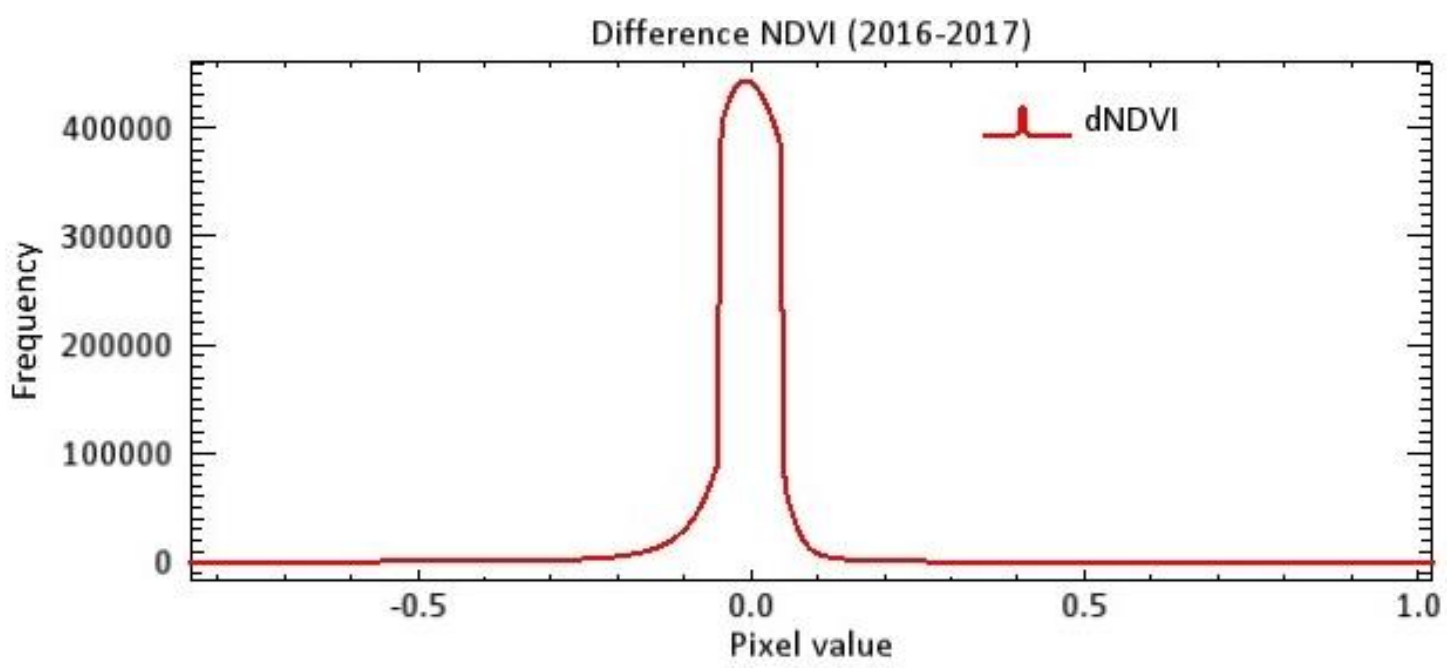

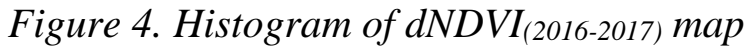

\subsection{Change classification map}

The left map in Figure 5 shows the spatial distribution of the dNDVI (2016-2017), and the map on the right of the figure determines the classification change forest in this study by selecting Otsu's automatic threshold. Of the three categories classes mapped inside the forest area, the forest class indicates the non-changed forest areas, the non-forest shows the previously deforested areas, and the deforestation class indicates cut-out forest areas between the years. 


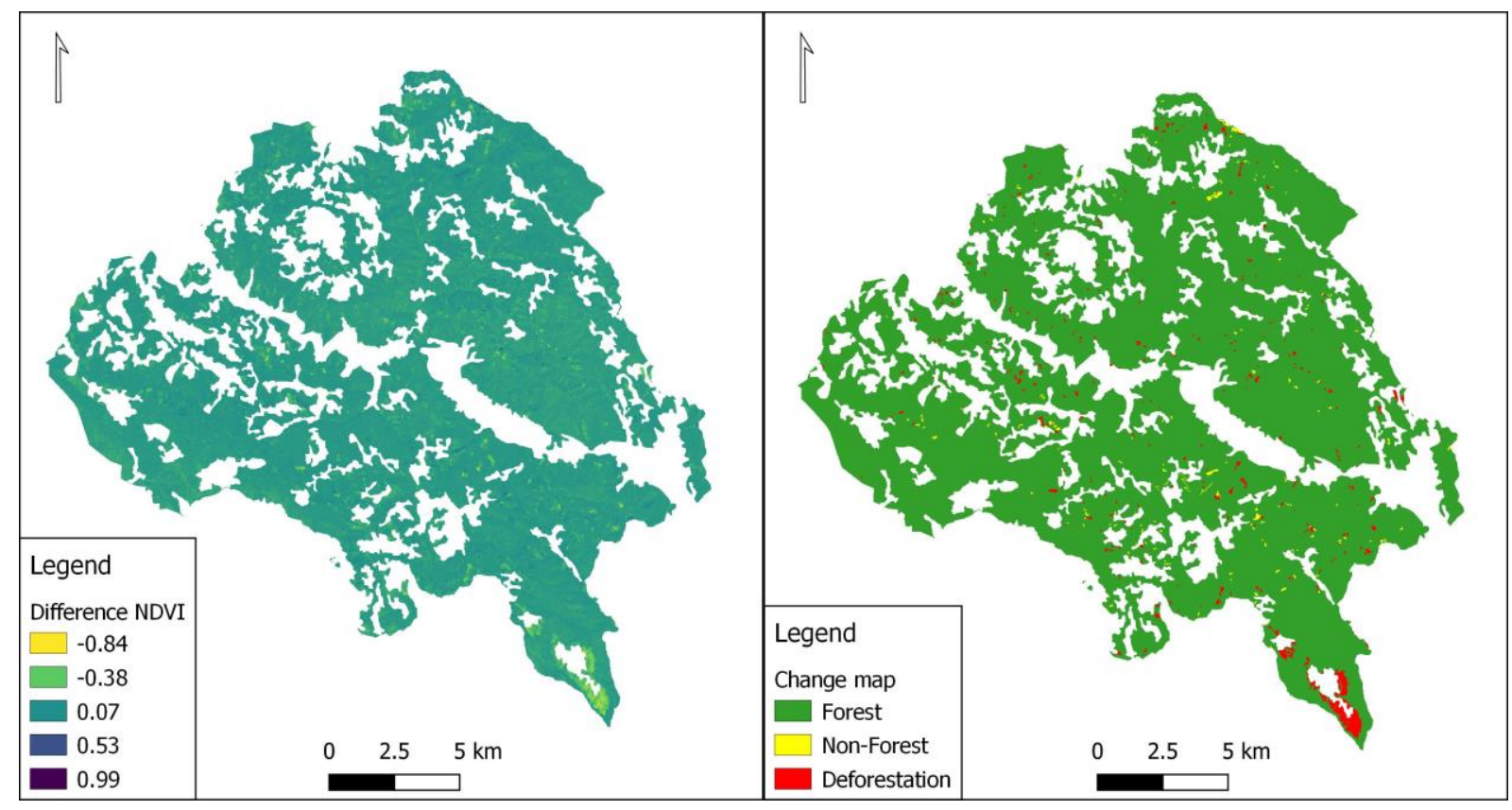

Figure 5. Difference $\operatorname{NDVI}_{(2016-2017)}$ map (left) and classification change map (right)

Table 5 shows the distribution of these three classes. Forest class covers the most class area with $98.19 \%$, the non-forest class has the least with $0.46 \%$, and deforestation class covers $1.35 \%$ of the total area and represents clear-cutting forest activity. Also, the description of the sampling size for each category class is in included in this table.

Table 5. Map category and sample size statistics

\begin{tabular}{lrrcc}
\hline \multirow{2}{*}{ Class name } & \multicolumn{2}{c}{ Classification statistics } & \multicolumn{2}{c}{ Sample size } \\
& Area $(h a)$ & Percent $(\%)$ & Number per class & $\begin{array}{c}\text { Total } \\
(\%)\end{array}$ \\
\hline Forest & 24423.57 & 98.19 & 50 & 33.33 \\
Non-Forest & 113.27 & 0.46 & 50 & 33.33 \\
Deforestation & 336.77 & 1.35 & 50 & 33.33 \\
Total & 24873.61 & 100.00 & 150 & 100 \\
\hline
\end{tabular}

\subsection{Sampling sites and verification}

Without the possibility of verifying field classification samples, time series of very high resolution (VHR) images on the Google Earth platform were utilized. All the category class samples (150) were covered with images in Google Earth and verified in the periods before and after the detection of forest cover changes (August 2016 - September 2017). In Figure 6, the yellow polygons represent the areas covered with forests in 2016, while the polygons in Figure 7 visually show the temporary removal of forest cover due to clear-cut. In Figure 8, the yellow polygons in the vast majority show the areas not covered with forests in 2016 that were deforested previously. On the other hand, in Figure 9, the yellow polygons clearly indicate that no artificial reforestation activities have occurred. 


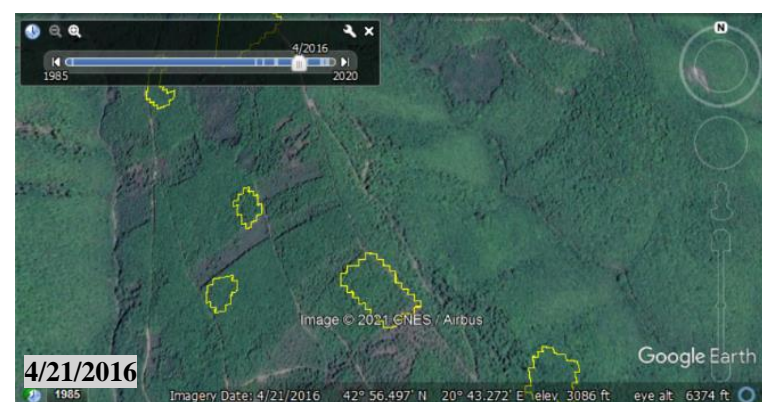

Figure 6. Yellow polygons indicate the forested area in 2016, visualized in GE

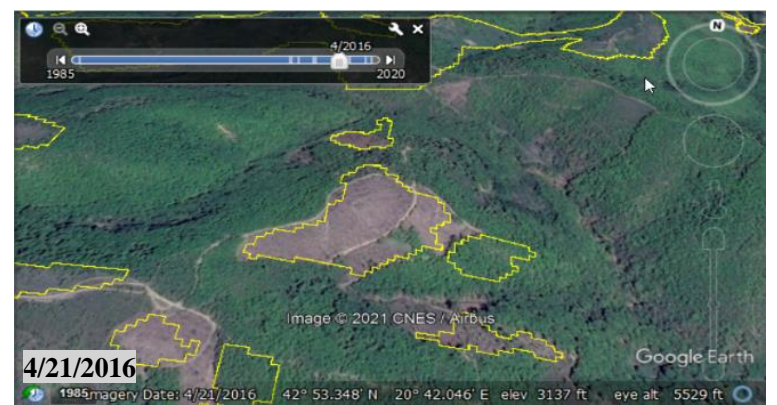

Figure 8. Example of the non-forested areas detected in 2016

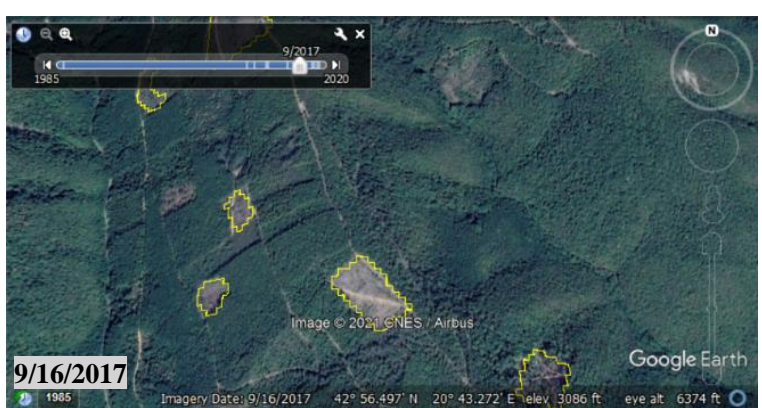

Figure 7. The clear-cut forested areas in 2017, interpreted and verified in $G E$

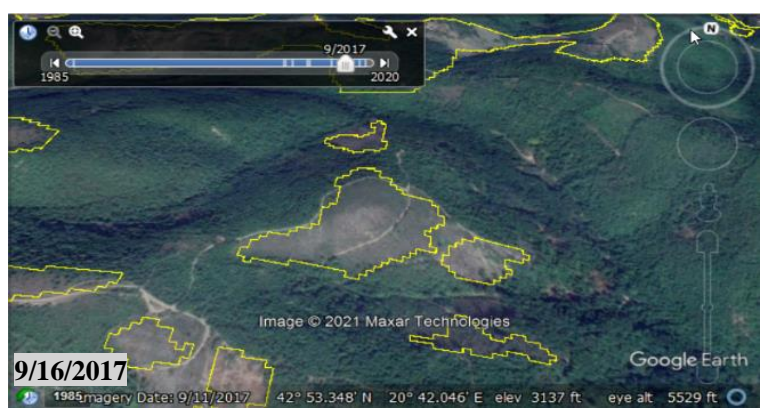

Figure 9. The yellow polygons of non-forested areas in 2017 shows no human reforestation

\subsection{Validation of classification change}

Quantitative accuracy assessment was utilized using the error (confusion) matrix in ENVI 5.3 software. Table 6 presents the error matrix of the reference data and classification change in percentage and number of pixels of the study area. From 50 samples of deforestation area, reference data shows that 40 belong to the deforestation class, eight to non-forest, and one of them remain in the forest class. From 50 samples of non-forest areas, eight were placed incorrectly in the deforestation class and none in the forest class. Only one sample site of the forest class belongs to the deforestation class.

Table 6. Error matrix table of reference data and classification change

\begin{tabular}{|c|c|c|c|c|c|}
\hline \multicolumn{6}{|c|}{ Reference data pixel and (percent) } \\
\hline \multirow{5}{*}{ 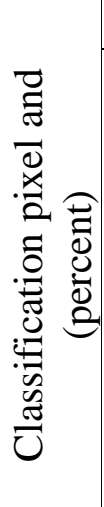 } & Class name & Forest & Non-Forest & Deforestation & Total \\
\hline & Forest & $\begin{array}{c}49 \\
(94.23)\end{array}$ & $\begin{array}{c}0 \\
(0.00)\end{array}$ & $\begin{array}{c}1 \\
(2.04)\end{array}$ & $\begin{array}{c}50 \\
(33.33)\end{array}$ \\
\hline & Non-Forest & $\begin{array}{c}0 \\
(0.00)\end{array}$ & $\begin{array}{c}42 \\
(85.71)\end{array}$ & $\begin{array}{c}8 \\
(16.33)\end{array}$ & $\begin{array}{c}50 \\
(33.33)\end{array}$ \\
\hline & Deforestation & $\begin{array}{c}3 \\
(5.77)\end{array}$ & $\begin{array}{c}7 \\
(14.29)\end{array}$ & $\begin{array}{c}40 \\
(81.63)\end{array}$ & $\begin{array}{c}50 \\
(33.33)\end{array}$ \\
\hline & Total & $\begin{array}{c}52 \\
(100.00)\end{array}$ & $\begin{array}{c}49 \\
(100.00)\end{array}$ & $\begin{array}{c}49 \\
(100.00)\end{array}$ & $\begin{array}{c}150 \\
(100.00)\end{array}$ \\
\hline
\end{tabular}

The overall accuracy of classification change is calculated by dividing the total sum of diagonal correctly classified pixels (131) by the total number of reference points (150). The compounded overall accuracy was $87.33 \%$. Producer accuracy is calculated by dividing each 
diagonal pixel value class by the total of each column. Table 7 shows that the highest producer's accuracy possesses forest area $(94.23 \%)$, then the non-forest areas ranges to $(85.71 \%)$, and the least have deforestation area around $81.63 \%$. User accuracy is calculated by dividing each of the diagonal pixel value classes by the total of each row. From the results of Table 6, the forest area has the highest user accuracy (98.00), followed by non-forest $(84.00 \%)$, and deforestation $(80.00 \%)$.

Table 7. Validation measurements of classification change

\begin{tabular}{lcccc}
\hline Class name & $\begin{array}{c}\text { Commission } \\
\text { error }(\%)\end{array}$ & $\begin{array}{c}\text { User accuracy } \\
(\%)\end{array}$ & $\begin{array}{c}\text { Omission } \\
\text { error }(\%)\end{array}$ & $\begin{array}{c}\text { Producer accuracy } \\
(\%)\end{array}$ \\
\hline Forest & 2.00 & 98.00 & 5.77 & 94.23 \\
Non-Forest & 16.00 & 84.00 & 14.29 & 85.71 \\
Deforestation & 20.00 & 80.00 & 18.37 & 81.63 \\
\hline
\end{tabular}

\section{DISCUSSION AND CONCLUSIONS}

Acquiring spatial information on vegetation status using geospatial technologies has become necessary for sustainable forest management. In this research, we used medium-spatial resolution satellite imagery of the Sentinel 2-A platform to detect and map the deforestation process between 2016 and 2017 within the forest area. The image difference method is easy to apply to conduct a grayscale image by subtracted vegetation indices (VIs) of two dates NDVI, but it is difficult to manually setup the appropriate thresholds. The application of the Otsu's threshold on the image differenced NDVI monochrome image (NDVI (2016-2017)) enabled us to detect and map the deforested and non-forested areas that were previously under forest. The results of accuracy assessment show that this approach is acceptable (overall accuracy was $87.33 \%$ ). Researchers have used different forest classification approaches, change detection methods, and algorithms to evaluate the forest cover change process. They have also utilised multi-spectral images and VIs. The VIs of the NDVI, enhanced vegetation index (EVI), and leaf area index (LAI) had derived from multi-spectral images used by Elhag et al. (2021) for mapping spatial-temporal land cover distribution, mapping bare soil index (BSI), and in identifying the significant land cover changes over 20 years (1995-2015) in the Sougia catchment of Crete Island, Greece. The VIs of NDVI was derived from Landsat data, EVI was derived from MODIS time-series and used as an optimized index, and LAI as NDVI derivatives to define up to ten land cover classes. The supervised image classification method using Support Vector Machine (SCM) train algorithm was applied to create land cover maps for three periods: 1995, 2005, and 2015 and to assess the classification accuracy. Their results compared with CLC categories map as ground truth data. The overall accuracy of the SVM classification algorithm was over $87.00 \%$ in three periods. As a change detection method, Elhag et al. (2021) used a post-classification comparison between the spanning times and revealed a significant depletion of $-14 \%$ in the coniferous forest from 1995 to 2015. Nath and Acharjee (2013) used the NDVI index to generate maps by slicing five ranges of NDVI applying the Jenks Natural Breaks classification method in their study area. The final step in their research was the creation of the vegetation cover change map, where NDVI categories map (decreased, some decreased, some increase, and increased) of 1989 and 2010 had crossed and revealed significant changes. From the total area (2893.59) hectares, reduced class shows $44.40 \%$, followed by some decrease $37.93 \%$ and remaining falls under some increase and increasing trend. Candra (2020) has developed a method to detect deforestation in his work in Kalimantan and Sumatera (Indonesia) using multitemporal satellite imagery from 2018-2019. 
He called this method Multitemporal Deforestation Detection (MDD). The main idea was to determine the difference between the reflection values in the targeted image (image that has deforested pixels) and in the original one (image without change of forest pixels). To develop this algorithm, Candra took two main steps: a) Band selection - several pixels representing the deforestation from the target and original image are taken, and the change in their reflection values is calculated. The bands that have the most significant changes in values from the results are selected and the threshold is also selected by performing some observations. b) With the created algorithm, the combination is made using NDVI and difference normalized burn ratio (dNBR) - to increase the accuracy of the results. The commission error results of deforestation detection were a total of $0.63 \%$, while, on the other hand, the omission error is $0.33 \%$. Given that the errors are small, this then provides the user accuracy and producer accuracy higher accuracy. Concerning our study, the selection of Equalized Stratified Random sampling strategy samples for classification verification has reduced the overestimation of the classification result, especially for the forest and non-forest class, which were the target of the classification. As the verification process of the samples relayed only VHR Google Earth images, field verification seems necessary in future research, especially to check the regeneration process at the early stage, which is not visible from satellite images. The difficulty during this study was that the work was based solely on using Remote Sensing and GIS desktop software, making it impossible to directly access platforms that offer real-time data for spatial analysis and change detection.

Therefore, in the future, such research would be easier and more resource intensive using modern web-based platforms such as Google Earth Engine (GEE), which provides high-speed data analysis for large spatial extents using processing function and provide algorithms to gather data from multiple years, satellite sensors and models (Zurqani et al. 2018). The results of the image difference method applied in this study revealed that forest cover in this municipality has changed both from human (forest cutting) and natural factors (forest fire). Based on the Kosovo Green Report 2018 (Report, 2018), during 2017, around $2.040 \mathrm{~m}^{3}$ of timber was confiscated from illegal loggers by communal authorities and 2.054 ha forests experienced fires in Kosovo. Illegal forest cutting is much related to the poor social and economic situation, especially in poor rural areas where forest resources are utilized for survival. From the overall forest-covered of $24,873.61$ hectares, $24,423.57$ ha or $98.19 \%$ mapped as forest cover, 113.75 hectares or $0.46 \%$ as non-forest, and 336.77 or $1.35 \%$ of the area forest mapped as deforestation. The percentage of deforestation area is worthy of attention, and in the future, we intend to investigate spatial-temporal forest cover changes till to present time.

\section{REFERENCES}

Addabbo, P. - Focareta, M. - Marcuccio, S. - Votto, C. - Ullo, L.S. (2016): Contribution of Sentinel-2 data for applications in vegetation monitoring. Acta IMEKO 5 (2): article 7. Identifier: IMEKO-ACTA-05 (2016)-02-07

Banskota, A. - Kayastha, N. - Falkowski, M. - Wulder, M.A. - Froese, R. - White, J.C. (2014): Forest monitoring using Landsat time-series data- A review. Canadian Journal of Remote Sensing 40 (5): 362-384. https://doi.org/10.1080/07038992.2014.987376

NATH, B. - ShukLa ACharJeE, Sh. (2013): Forest Cover Change Detection using Normalized Difference Vegetation Index (NDVI) : A Study of Reingkhyongkine Lake's Adjoining Areas, Rangamati, Bangladesh. Indian Cartographer 33: 348-353. https://www.researchgate.net/publication/271908557

CAmpbell, J. B. - WynNe, R.H. (2011): Introduction to Remote Sensing (Fifth Edition ed.). The Guilford Press, New York. 662 p. 
CAnada Centre for Remote Sensing. Fundamentals of Remote Sensing. Intermap Technologies Ltd, Calary and Ottawa, Canada. Online: https://www.nrcan.gc.ca/sites/www.nrcan.gc.ca/files/earthsciences/pdf/resource/tutor/fundam/pdf /fundamentals_e.pdf

CANDRA, S. D. (2021): Deforestation detection using multitemporal satellite images. In: Proceedings of the Fifth International Conferences of Indonesian Society for Remote Sensing. IOP Conference Series: Earth and Environmental Science. Indonesia. July 2020. 1-13. https://doi.org/10.1088/1755-1315/500/1/012037

Congalton, G. R. - GReEn, K. (2009): Assessing the Accuracy of Remotely Sensed Data: Principles and Practices (Second Edition). Taylor \& Francis Group, New York. 200 p.

Congalton, G. R. (2001): Accuracy assessment and validation of remotely sensed. International Journal of Wildland Fire 10: 231-328. https://doi.org/10.1071/WF01031

Coppin, P. - JonCKHEERE, I. - NACKAERTS, K. - MuYs, B. - LAMBIN, E. (2004): Review article digital change detection methods in ecosystem monitoring: a review. International Journal of Remote Sensing 25: 1565-1596. https://doi.org/10.1080/0143116031000101675

ElHAG, M. - BotevA, S. - Al-AmRI, N. (2021): Forest cover assessment using remote-sensing techniques in Crete Island, Greece. Open Geosciences 13 (1): 345-358. https://doi.org/10.1515/geo-2020-0235

ESA. (2015). SENTINEL-2 User Handbook.

EUROPEAN ENVIRONMENT AGENCY, (2018). Copernicus Land Monitoring Service. Online: https://land.copernicus.eu

Gillanders, S. N. - CoOPS, N. C. - Wulder, M. A. - Gergel, S. E. - Nelson, T. (2008): Multitemporal remote sensing of landscape dynamics and pattern change: describing natural and anthropogenic trends. Progress in Physical Geography 32 (5): 503-528. https://doi.org/10.1177/0309133308098363

Goward, S. - ARVidSON, T. - Williams, D. - FAundeEN, J. - IRONS, J. - FranKS, S. (2006): Historical record of Landsat global coverage: mission operations, NSLRSDA, and international cooperator stations. Photogrammetric Engineering and Remote Sensing 72 (10): 1155-1169.

Hojas-Gascón, L. - Belward, A. - Eva, H. - Ceccherini, G. - Hagolle, O. - Garica, J. CERUTTI, P. (2015): Potential improvement for forest cover and forest degradation mapping with the forthcoming Sentinel-2 program. The International Archives of the Photogrammetry, Remote Sensing and Spatial Information Sciences, XL-7/W3. https://doi.org/10.5194/isprsarchives-XL-7W3-417-2015

HuETE, A. R. - LIU, H. (1994): An error and sensitivity analysis of the atmospheric- and soil-correcting variants of the NDVI for the MODIS-EOS. IEEE Transactions on Geoscience and Remote Sensing 32: 897-905. https://doi.org/10.1109/36.298018

Hussain, M. - Chen, D. - Cheng, A. - Wei, H. - Stanley, D. (2013): Change detection from remotely sensed images: From pixel-based to object-based approaches. ISPRS Journal of Photogrametry and Remote Sensing 80: 91-106. https://doi.org/10.1016/j.isprsjprs.2013.03.006

IM, J. - JENSEN J.R. (2005): A change detection model based on neighbourhood correlation image analyses and decision tree classification. Remote Sensing of Environment 99: 326-340. https://doi.org/10.1016/j.rse.2005.09.008

Kosovo StATISTIC AgENCY (2013): ESTIMATION of Kosovo population 2011. Online: http://ask.rks-gov.net/media/2129/estimation-of-kosovo-population-2011.pdf

LEPRIEUR, C. - KERR, Y. H. - MASTORCHIO, S. - MEUNIER, J. C. (2000): Monitoring vegetation cover across semi-arid regions: Comparison of remote observations from various scales. International Journal of Remote Sensing 21: 281-300. https://doi.org/10.1080/014311600210830

Lu, D. - MAusel, P. - BAtistella, M. - MoRAN, E. (2005, online 2007): Land-cover binary change detection methods for use in the moist tropical region of the Amazon: a comparative study. International Journal of Remote Sensing 26: 101-114. https://doi.org/10.1080/01431160410001720748

Lu, D. - MAusel, P. - Brondizio, E. - Moran, E. (2004): Change detection techniques. International Journal of Remote Sensing 25: 2365-2407. https://doi.org/10.1080/0143116031000139863 
MaCleod D. R. - Congalton, G. R. (1998): A quantitative comparison of change-detection algorithms for monitoring eelgrass from remotely sensed data. Photogrammetric Engineering and Remote Sensing 64: 207-216.

MENESES-TOVAR, L. C. (2011/12): NDVI as indicator of degradation. Unasylva Vol. 62, http://www.fao.org/3/i2560e/i2560e07.pdf

MinistRy OF AGRICULTURE, ForESTRY AND RURAL DEVELOPMENT (2018): Kosovo Green Report 2018. Online: https://www.mbpzhr-ks.net/repository/docs/Raporti i Gjelber 2018.pdf

OTsu, N. (1979). A threshold selection method from gray-level histograms. IEEE Trans. SMC 9: 6266. https://doi.org/10.1109/TSMC.1979.4310076

SingH, A. (1989). Review Article Digital change detection techniques using remotely-sensed data. International Journal of Remote Sensing 10: 989-1003. https://doi.org/10.1080/01431168908903939

StORY, M. - CONGAlton, R.G. (1986): Accuracy Assessment: A User's Perspective. Photogrammetric Engineering and Remote Sensing 52: 397-399.

Tomter, S. M. - Bergsaker, E. - Muja, I. - Dale, T. - Kolstad, J. (2013): National Forest Inventory of Kosovo 2012. Ministry of Agriculture, Forestry and Rural Development. Online: https://nfg.no/wp-content/uploads/2019/01/Kosovo-National-Forest-Inventory-2012.pdf

TUCKER, C.J. - VANPRAET, C.L. - SHARMAN, M.J. - VAN ITTERSUM, G. (1985): Satellite remote sensing of total herbaceous biomass production in the Sengalese Sahel-1980-1984: Remote Sensing of Environment 17: 233-249. https://doi.org/10.1016/0034-4257(85)90097-5

UNFCCC. (2002). Report of the Conference of the Parties on its seventh session. UNFCCC. Online: https://unfccc.int/resource/docs/cop7/13a01.pdf. Morocco

ZuRQANi, H. - Post, C. - MikHAilova, E. - SchlautMan, A. - SharP, J. (2018) Geospatial analysis of land use change in the Savannah Rover Basing using Google Earth Engine. International Journal of Applied Earth Observation and Geoinformation 69: 175-185 https://doi.org/10.1016/j.jag.2017.12.006

WALKeR, J. J. - DE BEuRS, K. M. - WynNE, R. H. - GAO, F. (2012): Evaluation of Landsat and MODIS data fusion products for analysis of dryland forest phenology. Remote Sensing of Environment 117: 381-393. https://doi.org/10.1016/j.rse.2011.10.014

WRI (World Resource Institute) (2019): Global Forest Watch. WRI, Washington USA. Online: https://www.globalforestwatch.org/ 
